\title{
Economics of Rural Livelihoods: A Case Study of Bitter Kola Marketing in Akwa Ibom State, Nigeria
}

\author{
Asa Ubong Andem, Daniel Enwongo Aniedi, Ebong Effiong Okon \\ Department of Agricultural Economics and Extension, University of Uyo, Uyo, Akwa Ibom State, Nigeria
}

Email address:

keana0772@yahoo.com (A. U. Andem)

\section{To cite this article:}

Asa Ubong Andem, Daniel Enwongo Aniedi, Ebong Effiong Okon. Economics of Rural Livelihoods: A Case Study of Bitter Kola Marketing in Akwa Ibom State, Nigeria. American Journal of Agriculture and Forestry. Vol. 3, No. 6, 2015, pp. 260-263.

doi: 10.11648/j.ajaf.20150306.13

\begin{abstract}
The study examined the economics of bitter kola marketing in rural areas of Akwa Ibom State, Nigeria. A sample size of 120 bitter kola marketers was selected for the study using a two-stage sampling procedure. Data obtained were analysed using descriptive statistics and budgeting technique. Findings reveal that $61.7 \%$ of the respondents were females with an average age of 37 years; $58.3 \%$ were married and $85 \%$ had formal education. The average household size of the respondents comprised of six persons and their average years of bitter kola marketing experience was also six years. Budgetary analysis indicated the bitter kola marketing in the study area is profitable with a marketing efficiency of $135.2 \%$. Transportation costs, poor marketing channels, price fluctuation, perishability and seasonality of the product were the most severe constraints to bitter kola marketing faced by the respondents. -Findings recommend, among others, that the Government (State and Local Government) endeavour to provide basic infrastructure such as good road networks in the rural areas of the state since high cost of transportation was the most severe constraint to bitter kola marketing in the study area.
\end{abstract}

Keywords: Bitter Kola, Marketing, Rural Areas, Akwa Ibom State

\section{Introduction}

Garcinia kola commonly known as 'bitter kola' is an economic and highly valued nut-bearing tropical tree available in large quantity in West Africa [1]. The tree is commonly found in timid lowland forests of Nigeria, Cameroon, Ghana and the Benin Republic [2]. The tree produces edible and medicinal seeds which are widely consumed [3]. The nuts have a bitter taste, followed by slight sweetness hence the name 'bitter kola'. Despite its bitter taste, Garcinia kola nuts are commonly eaten as snacks and used for their stimulant effects due to high caffeine content [4].

Garcinia kola has great economic value across West Africa; and the seeds are of particular importance in the social-cultural lives of the people in the tropics[5]. The nuts of bitter kola are highly valued for their perceived medicinal attributes, and consumption of large quantities of them does not cause indigestion[6]. [7] reported that the seeds, nuts and bark of Garcinia kola plants have been used extensively in African traditional medicine for the treatment of various diseases. Currently, Garcinia kola is being harnessed as a cure for Ebola virus infection and flu[8]. Its economic contribution to both domestic and national markets, according to [9], raises the standard of living of those involved in its trading activities both in the rural and urban centers. Trading in bitter kola is more profitable than trading in non-timber forest products in most developing countries [6]. This is because of the high amenability of bitter kola (both in fresh and dried forms) to storage. In Nigeria, where employment opportunities for traditional industries are declining, workers looking for alternative sources of income often turn to the collection of non-timber forest products, such as bitter kola, from nearby forests[10].

Inspite of the importance of bitter kola, there has been a dearth of information on the profitability of bitter kola marketing in the rural areas of Akwa Ibom State, Nigeria[11]. This study, therefore, aimed at filling this research gap by ascertaining the economics of bitter kola marketing in rural areas of Akwa Ibom State, Nigeria. Specifically, the objectives were to examine the socio-economic characteristics of bitter kola marketers in the rural areas of Akwa Ibom State, determine the profitability of bitter kola marketing in the study area and ascertain the constraints to bitter kola marketing in the study area. 


\section{Methodology}

The study was -conducted in AkwaIbom State - that lies within the South-Eastern axis of Nigeria, wedged between Cross River, Abia and Rivers States. On the southern margins of the State is the Atlantic Ocean which stretches from Ikot Abasi Local Government Area to Oron Local Government Area. The Administrative Capital of the State is Uyo Local Government Area. The State lies between $4^{0} 3$ " and $5^{0} 3$ " North latitudes and $7^{0} 35^{\prime \prime}$ and $8^{0} 25^{\prime \prime}$ East longitudes. It has an estimated population of 3,920,208 -out of the total land area of $7,245,935 \mathrm{~km}^{2},[12]$. A two-stage sampling procedure was employed for this study. The first stage involved the simple random selection of three out of the six Agricultural Development Project (ADP) zones in Akwa Ibom State. The selected ADP zones were Abak, Ikot Ekpene and Uyo and, the second stage of the sampling procedure involved the purposive selection of forty bitter kola marketers from rural areas in each of the three selected ADP zones. Purposive sampling was employed to ensure that only bitter kola marketers in the rural areas of the zones were selected for the study. -Selection resulted in a sample size of 120. Data collection was done through primary sources using a validated questionnaire. -The study wascarried out between January 2014 and October 2014.

Analysis of data was done using descriptive statistics and budgetary analysis. Frequency counts, percentages, means and ranks were used to analyse the socio-economic characteristics of bitter kola marketers in rural areas of Akwalbom State. Budgetary analysis was employed to estimate the cost, revenue, gross margin and net profit accruable to the marketers. The equation used in estimating the gross margin is defined below:

$$
\mathrm{GM}=\mathrm{TR}-\mathrm{TVC}
$$

Where:

$\mathrm{GM}=$ Gross Margin, $\mathrm{TR}=$ Total Revenue and $\mathrm{TVC}=$ Total Variable Cost

The equation used in ascertaining the net profit is as follows:

$$
\text { Л }=\mathrm{TR}-\mathrm{TC}
$$

Where:

Л $=$ Profit

$\mathrm{TR}=$ Total Revenue

$\mathrm{TC}=$ Total marketing Cost

The efficiency of marketing was measured by ShepherdFutrel model for accurate measurement of efficiency in the productivity of resources invested in the marketing process in quantitative terms[13]. The model is given as:

$$
\mathrm{ME}=\frac{T R}{T C} \times 100
$$

Where:

$\mathrm{ME}=$ Marketing Efficiency

$\mathrm{TC}=$ Total marketing Cost

\section{$\mathrm{TR}=$ Total Revenue}

In order to ascertain the constraints to bitter kola marketing faced by the respondents, twelve constraints were identified through Focus Group Discussions (FGDs), interviews and literature; and the respondents were requested to indicate the severity in each of the constraint item. This was done with the aid of a 3-point rating scale, with nominal values assigned to the points in the scale, as follows: Not a constraint $=1$, Mild constraint $=2$ and Severe constraint $=3$. A mean score was computed for each constraint item, and the mean score was used to rank the constraints in order of severity.

\section{Results and Discussion}

Table 1. Socio-economic characteristics of bitter kola marketers in Akwa Ibom State.

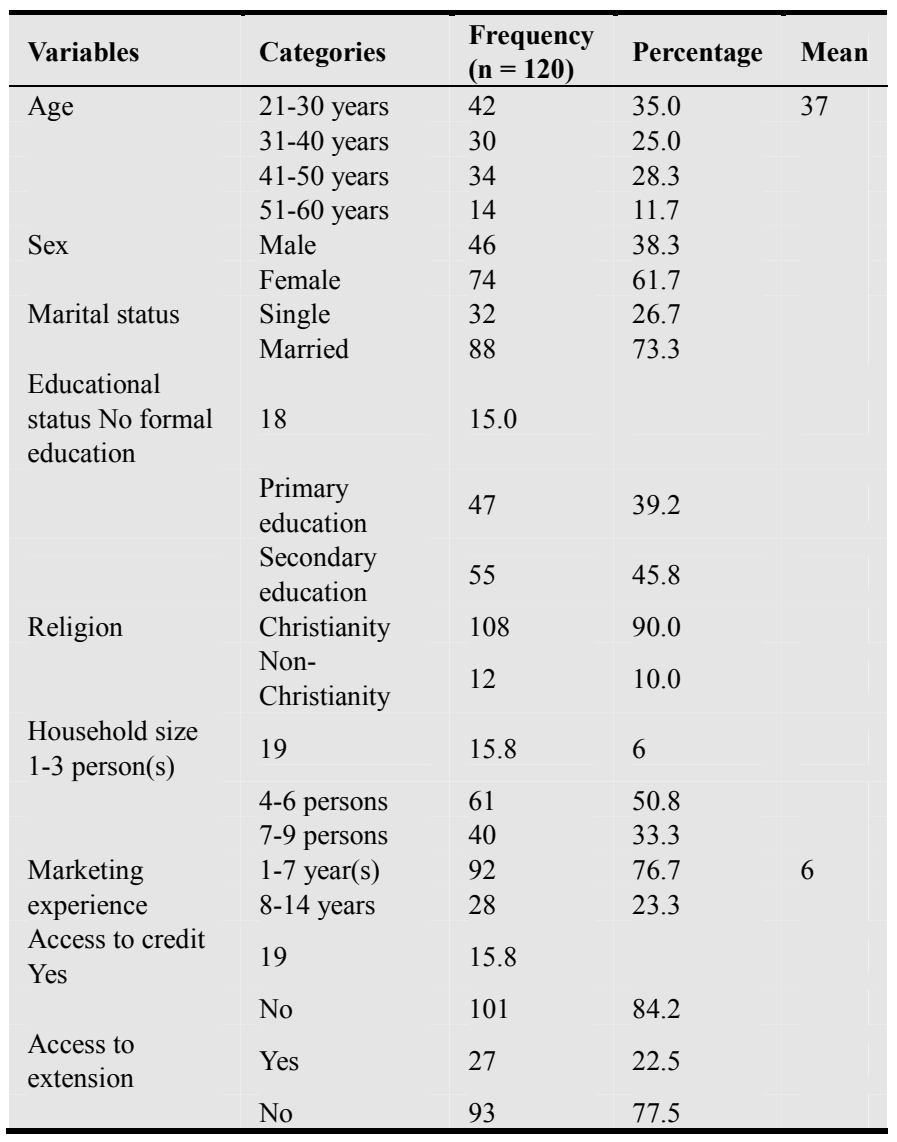

Source: Field Survey data, 2014

Socio-economic characteristics of bitter kola marketers: Table 1 shows the socio-economic characteristics of bitter kola marketers in Akwa Ibom State. The Table reveals that the mean age of bitter kola marketers in the study area was 37 years which agrees with [14] who reported that majority of the bitter kola marketers in Nigeria were within the age range of $20-50$ years. About $61.7 \%$ of the respondents were females and majority of them (58.3\%) were married. Marriage is a highly cherished value among people in rural areas of Akwa Ibom State, Nigeria[15]. From the table, majority of the respondents had formal education $(85.0 \%)$ and $-90.0 \%$ were Christians. [16] reported a high level of 
literacy among fruit marketers in Akwa Ibom State. The average household size of the respondents comprised of six persons. The finding agrees with [17] who reported that the average household size of rural dwellers in Akwa Ibom is low. The average years of experience in bitter kola marketing of the respondents was six years, which is relatively low. Over eighty four percent of the respondents (84.2\%) had no access to credit facilities and $77.5 \%$ of them had no access to extension services.

Profitability of bitter kola marketing in the study area: Table 2 shows the profitability of bitter kola marketing ascertained using budgetary analysis. - The total cost of marketing bitter kola during the period of the studywas $\$ 2$, $524,590.00$ and the total revenue of $\$ 3,413,591.00$ was realized, hence a net profit of $\$ 889,001.00$ was realized from sales of bitter kola by the marketers between January, 2014 to October, 2014. The net profit shows that bitter kola marketing in the study area was profitable. The finding agrees with [11] who reported that bitter kola marketing is a profitable enterprise in Akwa Ibom State. [6] also reported that bitter kola trading is a significant economic livelihood of people in the rain forest and derived savanna ecological zones of Nigeria. The marketing efficiency of bitter kola marketing in the study area was 135.2 as shown in Table 2. This implies that bitter kola market in the study area is efficient.

Table 2. Budgetary analysis of bitter kola marketing in rural areas of Akwa Ibom State, Nigeria.

\begin{tabular}{ll|l}
\hline Item & $\begin{array}{l}\text { Total cost for all } \\
\text { respondents (N) }\end{array}$ & $\begin{array}{l}\text { Percentage of } \\
\text { TC }\end{array}$ \\
\hline A. Fixed cost & & \\
Basin & $57,000.00$ & 2.26 \\
Bags & $4,600.00$ & 0.18 \\
Rent & $235,970.00$ & 9.35 \\
Tax & $89,150.00$ & 3.53 \\
Equipment/machinery & $180,450.00$ & 7.15 \\
Total Fixed Cost (TFC) & $567,170.00$ & 22.47 \\
B. Variable cost & & \\
Supply Price & $1,385,000.00$ & 54.86 \\
Transportation & $218,000.00$ & 8.64 \\
Labour & $209,930.00$ & 8.32 \\
Processing cost & $40,022.00$ & 1.59 \\
Wheel barrow hire & $72,250.00$ & 2.86 \\
Storage & $13,408.00$ & 0.53 \\
Water & $18,810.00$ & 0.75 \\
\hline Total Variable Cost (TVC) & $1,957,420.00$ & 77.53 \\
Total Cost = TFC + TVC & $2,524,590.00$ & 100 \\
C. Total Revenue (TR) & $3,413,591.00$ & \\
D. Net Profit, Л & $889,001.00$ & \\
E. Gross Margin (GM) & $1,456,171.00$ & \\
E. Marketing efficiency (ME) & 135.2 & \\
\hline Not & & \\
\hline
\end{tabular}

Note: Naira $(\mathbb{N})$ is the Nigerian currency and 1.00 US Dollar is equal to 199.20 Nigerian Naira as at November 7, 2014

Source: Computed from Field Survey data, 2014

Constraints to bitter kola marketing in rural areas of Akwa Ibom State: Table 3 shows the constraints to bitter kola marketing faced by_the respondents in the study area. Transportation cost $(x=\underline{0} .99)$, poor marketing channels ( $x=$ $0.98)$, price fluctuation ( $\bar{x}=0.88)$, perishability $(x=083)$ and seasonality of the product ( $x=0.81$ ) were the most severe constraints to bitter kola marketing in rural areas of Akwa Ibom State. The findings corroborate [18] who reported that transportation, irregular supply of product, poor marketing and price fluctuation were major challenges facing the marketing of non-timber forest products such as bitter kola in Nigeria. [19] opined that price fluctuation as a major constraint to bitter kola marketing is due to the fact that the forest fruits are not always available throughout the year due to their seasonal nature and perishability which makes them scarce leading to unwarranted changes in prices of the fruits. The least severe constraints to bitter kola marketing in the study area were: lack of relevant extension services ( $x$ $=0.50)$ and high cost of registration/selling permit ( $x=0.48)$.

Table 3. Constraints to bitter kola marketing in rural areas of Akwa Ibom State.

\begin{tabular}{l|l|l}
\hline Constraints & Mean & Rank \\
\hline 1. Transportation cost & 0.99 & 1 \\
2. Lack of storage facilities & 0.66 & 7 \\
3. Price fluctuation & 0.88 & 3 \\
4. Deforestation & 0.59 & 10 \\
5. Lack of modern processing technologies & 0.63 & 8 \\
6. Seasonality of the product & 0.81 & 5 \\
7. Lack of capital/finance & 0.69 & 6 \\
8. Poor marketing channels & 0.98 & 2 \\
9. Perishability & 0.83 & 4 \\
10. Lack of relevant extension services & 0.50 & 11 \\
11. Poor patronage & 0.62 & 9 \\
12. High cost of registration/selling permit & 0.48 & 12 \\
\hline
\end{tabular}

Note: $*=$ Rank 1 is considered the most severe constraint while rank 12 is the least severe constraint

Source: Field Survey data, 2014

\section{Conclusions and Recommendations}

The study has shown that bitter kola marketing in the rural areas of Akwa Ibom State is profitable as evidenced from the result of budgetary analysis. The study also revealed that the most severe constraints to bitter kola marketing in the study area were: transportation cost, poor marketing channels, price fluctuation, perishability and seasonability of bitter kola nuts.

Based on the findings of the study, the following recommendations are made:

a. The Government (State and Local) should endeavour to provide basic infrastructure such as good road networks in the rural areas of the state since high cost of transportation was the most severe constraint to bitter kola marketing in the study area.

b. The officials of the Ministry of Agriculture in Akwa Ibom State, Non-Governmental Organisations and Community-based Organisations organize training programmes on effective marketing for rural-based bitter kola marketers in the State since poor marketing channel was another major constraint to bitter kola 
marketing faced by the respondents.

c. Subsidized storage facilities /modern processing equipment should be made available to bitter kola marketers by both Governmental and NonGovernmental agencies in the State.

d. Bitter kola marketers in the study area should endeavour to form co-operatives to enhance their ability to access storage and transportation facilities thereby overcoming some of the major constraints to their marketing activities.

\section{References}

[1] Ikpesu, T. O., Tongo, I. and Ariyo A. (2015) Restorative Prospective of Powdered seeds extract of G. Kola in Chrysihthysfurcatus induced with Calyphosate Formulation, Nature and Science, 13 (11): 91-100.

[2] Unaeze, H. C., Oladele A. T. and Agu, L. O. (2013) Collection and marketing of bitter cola (Garcinia kola) in Nkwerre local Government Area, Imo state, Nigeria, Egyptian Journal of Biology, (1) 5: 37-43.

[3] Okigbo, B. N. (1977) Neglected plants of importance in traditional faming system of Tropical Africa, Acta. Horticulture, 5(3): 131-150

[4] Ayensu, E. S. (1978) Medicinal Plants of West Africa, Reference Publ.Inc. Algonac, ML., U.S.A, pp 162-163.

[5] Adebayo, S. A. and Oladele, O. I. (2012) Medicinal values of kolanut in Nigeria: implications for extension service delivery, Life Science Journal, 9 (2): 887-891.

[6] Adebesi A. A. (2004). A case study of Garcinia kolanut production to consumption system in $\mathrm{J} 4$ area ofomo forest reserve south west Nigeria. In: sunder land T. and Ndoye O. (eds) forest products livelihoods and conservation case studies of non-timber forest products systems. Vol. 2. Africa. CIFOR ISBN 979-3361-25-5. pp 115-132.

[7] Okoli, U. J., (1991). An Investigation into the Hypoglycemic Activity of GBI Biflavonoids of Garcinia kola, B. Pharm. Project, University of Nigeria, Nsukka.

[8] Adaramonye, O. A., Nwaneri, V. O. Anyanwu, K. C., Farombi, E. O. and Emerole, G. O. (2009) Possible antiantherogenic effect of kolaviron (a Garcinia kola seed extract) in hypercholesterolaemicrats, African Journal of Biotechnology, 32(1-2): 40-46.
[9] Yakubu, F. B., Adejoh, O. P.,Ogunade, J. O. and Igboanugo, A B. I. (2014) Vegetative propagation of Garcinia kola (Hcckel), World Journal of Agricultural Science, 10 (3): 85-90.

[10] Adepoju, A. A. and Salau, A. S. (2007) Economic valuation of Non-Timber forest products MPRA. Paper No. 2689.Available online at http://mpra.ub.uni-muenchen.de/2689/. Accessed on August 08, 2007.

[11] Akpan, V. U. (2015) Economics of the bitter kola marketing in Uyo Metropolis of Akwa Ibom State, B. Agric, Department of Agricultural Economics and Extension, University of Uyo, Uyo. 65pp.

[12] National Population Commission (2006) Population and Housing Census of the Federal Republic of Nigeria. Analytical Report at the National Population Commission, Abuja, Nigeria.

[13] Omofonwam, E. I., Ashaolu O. F., Ayinde I. A. and Fakoya E. O. (2013) Assessment of palm wine market in Edo State, Journal of Science and Multidisciplinary Research, 5(2): 141 -151 .

[14] Agbelade, A. D. and Onyekwelu, J. C. (2013) Poverty alleviation through optimizing the marketing of Garcinia kola and Irvingia Gabonensis in Ondo State, Nigeria, Hindawi Publishing Corporation, Nigeria, pp 1-5.

[15] Ekong, E. E (2003) An Introduction to Rural Sociology (2 ${ }^{\text {nd }}$ Edition), Dove Educational Publishers, Uyo, Nigeria. pp 341395.

[16] Ekerete, B. A. and Asa, U. A. (2014) Constraints to watermelon marketing in Uyo Metropolis of Akwa Ibom State, Nigeria, Journal of Agricultural and Environmental Sciences, 3 (4): 63-69.

[17] Asa, U. A. and Eyo, E. J. (2015) Constraints to palm wine marketing in rural areas of Akwa Ibom State, Nigeria, British Journal of Science, 13 (1): 45-52.

[18] Yusuff, A. O., Adams, B. A., Adewole, A. T. and Olatoke, T. I. (2014) NTFPs collection as an alternative source of income for poverty alleviation among rural farmers in Egbeda Local Government Oyo State, Academic Journal of Interdisciplinary Studies, 3(6): 467-474.

[19] Famuyide, O. O., Adebayo, O. Arabomen, O. and Jasper, A. A. (2012) Economic assessment of marketing of non-wood forest products in Ibadan Metropolis, Elixir International Journal, 52 (2012): 11645-11649. 